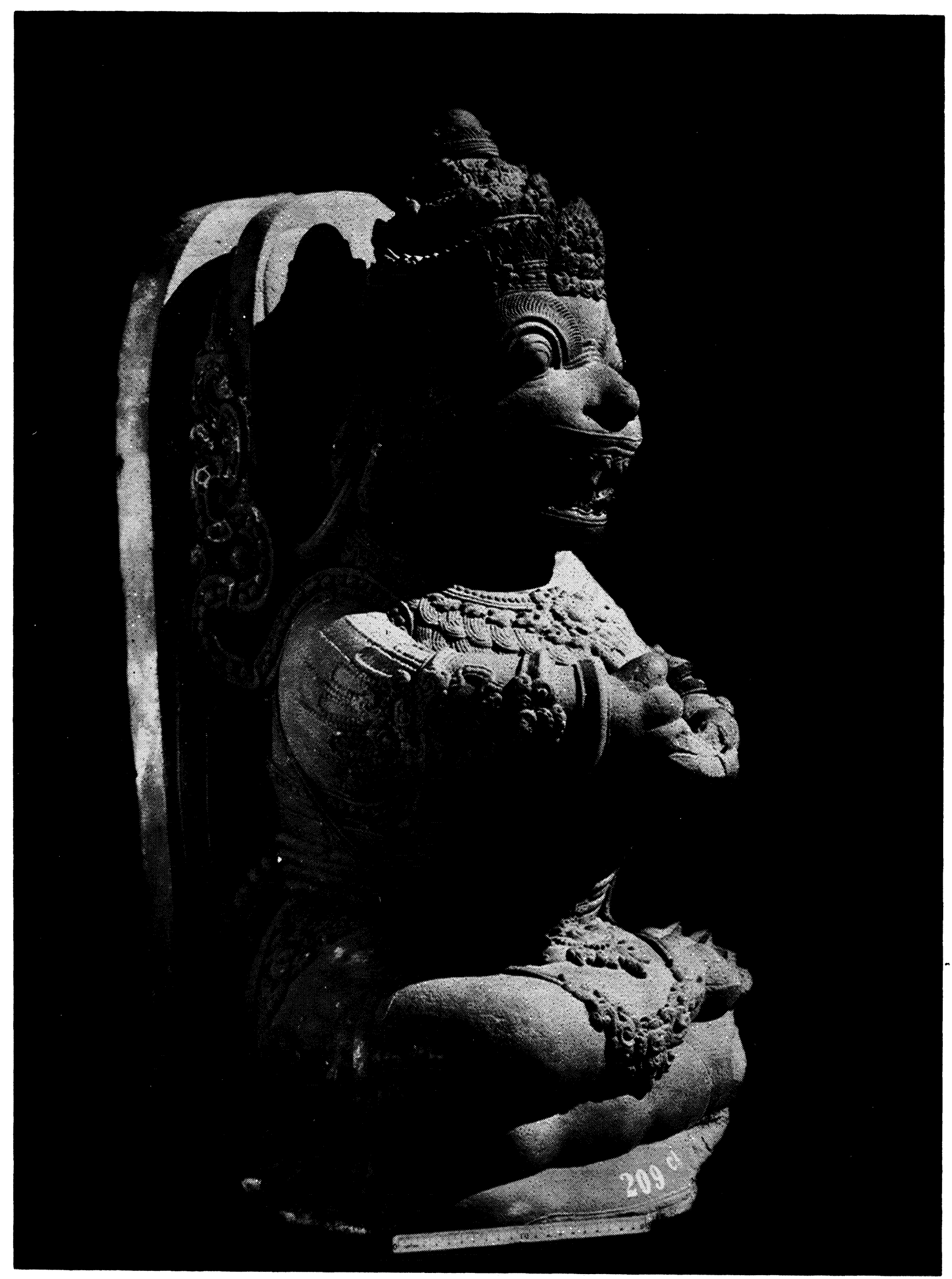


Onghokham

The wayang-topèng is a dance drama performance based on the stories of the Pandji-cycle with the actors wearing masks or topeng while the dalang ${ }^{1}$ telis the story. This art form is known throughout Java. Several regions, however, are known for their own style of masks, costumes, and style of dancing. In this article, the Malang (East Java) wayang topèng tradition will be described.

Malang has long been a center of topèng culture. "Kepandjèn" is a place name in the area taken from the wayang, Pandji. In the 1930's this tradition received notice from Dr. Th. Pigeaud in his standard volume on Javanese Volksvertoningen (Javanese popular performances). ${ }^{2}$ One of Pigeaud's informants was then the bupati ${ }^{3}$ of Malang, Raden Adipati Soerio-adiningrat, a great patron of the arts and especially of Malang topèng. The bupati's own famous collection of Malang topèng masks is still displayed today in the Sono Budojo Museum of Jogjakarta. Some other masks of his collection found their way into another "national collection," that of the late Prince Mangkunegara VII of Surakarta probably because the Raden $\mathrm{Ayu}^{4}$ was a granddaughter of Mangkunegara II. In the kabupatèn of Malang itself Dr. Th. Pigeaud noted in the 1930's the existence of as many as twenty-one sets of masks each containing forty to sixty topèng. How many sets there are today is not known though each set still conventionally contains forty to sixty masks. Dr. Pigeaud and the bupati ended their observations with a pessimistic view on the future of the wayang topèng tradition of Malang.

Today, one has still more reason to be pessimistic. The increase of travel between the different parts of Java and the influence of radio broadcasting from the urban centers have caused centralizing tendencies in Javanese culture at the cost of local art traditions. Javanese art has become more and more concentrated in the urban centers; the Zudruk ${ }^{5}$ of Surabaja, the ketoprak of Jogjakarta and the

1. The puppeteer of the wayang who sings, jokes, narrates, cues the gamelan, philosophizes, and manipulates the puppets.

2. Dr. Th. Pigeaud, Javaanse Volksvertoningen. Bijdragen tot de Beschrijving van Land en Volk (Djakarta: Volkslectuur, 1938), pp. 141-147.

3. The head of a kabupatèn (district). During the colonial period the largest territorial unit under an Indonesian. Regent is the Dutch equivalent.

4. The title for the wife of a bupati in pre-Independence Java.

5. A modern East Javanese theatrical form with Surabaja as one of its main centers. The plays performed are not based solely on Javanese mythology and history but are derived from the broad social and political arena of everyday life. 


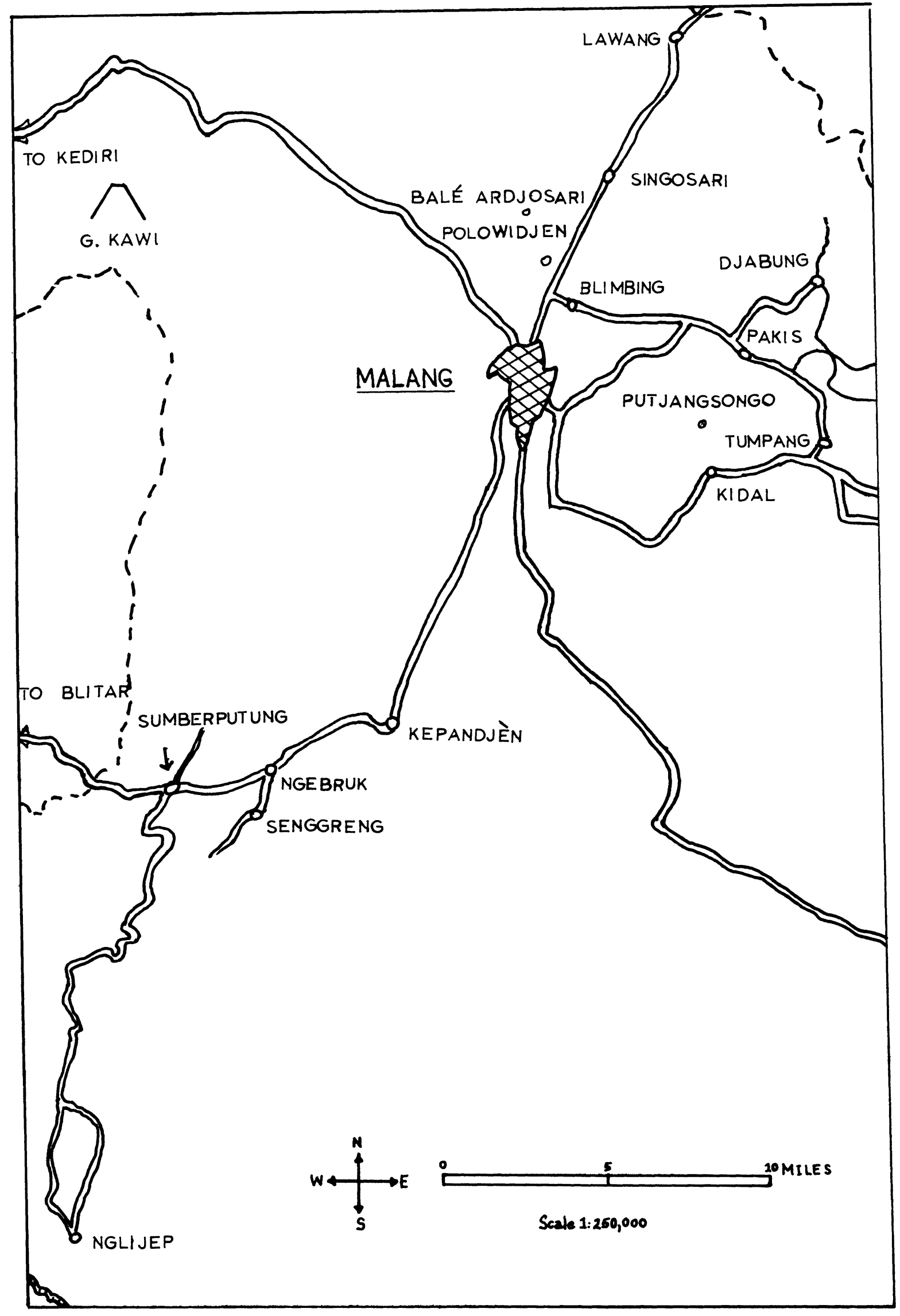


wayang-orang ${ }^{7}$ and wayang-kulit ${ }^{8}$ of Surakarta have become the focus of attention.

In the town of Malang itself one is hardly aware of the existence of a local Malang wayang topèng tradition. It has been overshadowed by the other art forms. Today if an open air theater performance is organized in Malang, a version of the Prambanan Ramayana is likely to be produced, although the wayang topeng of Malang would lend itself excellently for this. The last time a wayang topèng from the area was shown in Malang was in 1956 or 1957 when there was another bupati, R. Djapan, with an interest in local Malang art. Now one has to go to the rural areas of the kabupatèn to find what remains of the Malang wayang topèng tradition.

In rural Malang a wayang topèng is held on the occasions of marriages, circumcisions, the village festivities of Bersih Desa (annual village cleansing festival after the harvest), or on national holidays. I had the opportunity to see several of these village performances. I will try to locate geographically the centers of the wayang topèng, and to describe the organization and personalities of a performing group, the mask carvers and patrons of the wayang topèng, and the influence of topèng artists in the past on present day wayang cus toms.

\section{The Performance}

In 1963 I saw a wayang topèng performance at the village of Djabung, about twenty kilometers northeast of Malang. To reach Djabung one goes west towards Tumpang and then turns five kilometers north at Pakis on an unpaved road, usually only travelled by dokar ${ }^{9}$ and buffalo-drawn tjikar, 10 which leads to the village. Djabung is somewhat isolated although it lies in a fertile and rather prosperous region shown by a large and handsome langgar (prayer-house) and large we11-built houses in the area. The performance was held on the occasion of the village's Independence Day celebrations on the 17 th of August. It started at $8 \mathrm{P} . \mathrm{M}$. and finished at about $3 \mathrm{~A} . \mathrm{M}$.

The performance was held at the large house of the wayang topèng leader in a temporary structure of bamboo adjoining the front of the

6. A folk-play which usually enacts stories depicting ancient Javanese times.

7. A dance-drama of Centra1 Java portraying the Ramayana and Mahabharata stories, and employing people as actors.

8. Literally, "shadow play," a theatrical form using leather puppets, but the term refers to those shadow plays in which the purwa cycle of plays are performed.

9. Dog-cart. A light one-horse carriage, commonly two-wheeled, with two transverse seats set back to back for passengers.

10. A heavy cart drawn by buffaloes for transporting materials or goods. 
house to simulate a pendopo. ${ }^{11}$ Across the width of this pendopo hung a curtain painted with palaces, mountains, and tjandis ${ }^{2}$ of $10 \mathrm{cal}$ fame. The gamelan (Javanese orchestra), a pélogi set, was in front of the stage while the audience surrounded it on three sides. The dalang sat in front of the gamelan as at a wayang purwal ${ }^{4}$ or wayang kulit performance, but without a screen, with a banana trunk in front of him and a kayon or gunungan ${ }^{15}$ planted on the trunk. Above the dalang hung a blentjong, ${ }^{16}$ now usually a petromax lamp. On the whole the performance gave the impression of a wayang kulit performance with living actors on the stage being manipulated by the dalang, who tells the story, imitates the different voices and holds the dialogue between the different characters, except where the punakawan ${ }^{17}$ (clowns, jesters and companions of the chief hero) are concerned. They speak their own dialogue, made possible by wearing half masks which leave their mouths uncovered.

Formerly the performance was introduced by a bapang dance, a kelana ${ }^{18}$ dance of forceful gestures and postures by a dancer wearing a red mask with an extraordinary long nose. This dance has disappeared from the Malang wayang topèng performance and has not been seen since pre-war days, though there are still some dancers who can do it. The ngremo, 19 a solo dance-song number by an adult male dancer has replaced the bapang dance as an introduction to the performance. This ngremo dancer sang a wizudjeng (wiludjeng para tetamu--"welcome honored guests") song.

After the ngremo the gamelan played the talu (prelude). The dancers came out one by one in full costume as the dalang introduced

11. The front hall of a traditional Javanese house. The ceiling and roof rest on pillars while there are no walls except where the back side adjoins the house. Social life traditionally centers around this hall.

12. Hindu temple.

13. Scale of gamelan tuning in which the octave is divided into seven notes.

14. Wayang kulit performances in which the original cycles of Javanese mythology are depicted, especially the Pandawa cycle.

15. A leaf-shaped leather puppet combining the images of the tree of life and Mount Meru. It is used in wayang performances as the play's setting and as a curtain to divide scenes.

16. Traditionally an oil lamp with a big flame which hung above the dalang and provided the light for shadow plays. Symbolically, it represented the source of life, or the sun.

17. The punakawan are usually played by child dancers in Malang wayang topèng. They often give a parody or imitation of village life causing great laughter.

18. Warrior figure or giant.

19. An East Javanese coastal song now often given as an introduction to ludruk performances. 
their roles in the coming performance so that the audience could recognize them during the play. After a pause of a few minutes, the wayang topeng performance began with the dalang taking the kayon from the banana trunk and speaking the traditional sentences which begin "swuh rep data pitana..." (be quiet, be calm... .). The actors entered for the first djedjer (major scenes, usually in the main hall of a palace).

The masks worn by the dancers were typical of Malang. Several differences with those of Central Java should be noted. The masks are held by strings around the head and not by a leather piece in the mouth. Unlike the halus ${ }^{20}$ style of Central Java, the Malang mask is made of thick heavy wood and fashioned with a square chin, high cheekbones and deeply carved features. The djamang (diadem) on the front head of the mask is equally richly carved. The moustaches of the gagah ${ }^{1}$ figure of Malang are always carved while those of Central Java are painted or replaced by real or fake hair. The Malang mask always has a closed mouth while the mask from Central Java has an open mouth.

Other parts of the topèng dancer's costume are the leather djamang on the dancer's head, leather sumping (ear ornaments), a short velvet jacket embroidered with gold and silver over a white T-shirt or a black velvet embroidered breast plate, a short skirt of the same material covering the front and bound around the waist, pandjèn (wide black trousers reaching to the knees), and less esthetic, football socks to protect the feet from splinters. Finally, essential to the costume are the sampur (dancer's waist sash) and the string of bells tied around the ankles called gongsèng or krintjing.

The sampur's elaborate function in all Javanese dance is well known. The gongsèng, however, are unique to wayang topèng. The bells emphasize the dramatic effect of the dancer's movements and draw the audience's attention to them. They function like the ketjrèk 22 at the wayang purwa performance. The dancers stamp their feet making the bells ring. They also shake the bells to accompany the gamelan.

This performance did not give the impression of being as well structured as wayang purwa with its fixed sequence of scenes. The punakawan such as Patradjaja, Besut and others came on earlier and more frequently. The figures of the Pandji cycle spoke no words themsleves and the performance was entirely a dance drama. There were (at most) six or seven dancers at the same time on the small stage. The drama seemed to consist of a continuous marching on and off stage, fights, and dancing in a circle interrupted by dramatic poses of the halus and gagah figures. However the dancing itself was dramatic and forceful. Every time a figure left or came onto the stage it was taken as an opportunity to dance around in a circle and rearrange the harmony of the stationary formation of dancers on the stage. This kept the audience spellbound for seven hours. Indeed the moving heads

20. Refined, related to ksatria (knight).

21. Proud, cocky figures, often giants and warriors.

22. Pieces of metal strung on rope and clacked by the dalang to announce arrivals and departures of puppets or to accentuate their movements. 
Bapang Dancer

Source: Dr. Th. Pigeaud, $\frac{\text { Javaanse Volksvertoningen, }}{\text { plate XIII. }}$

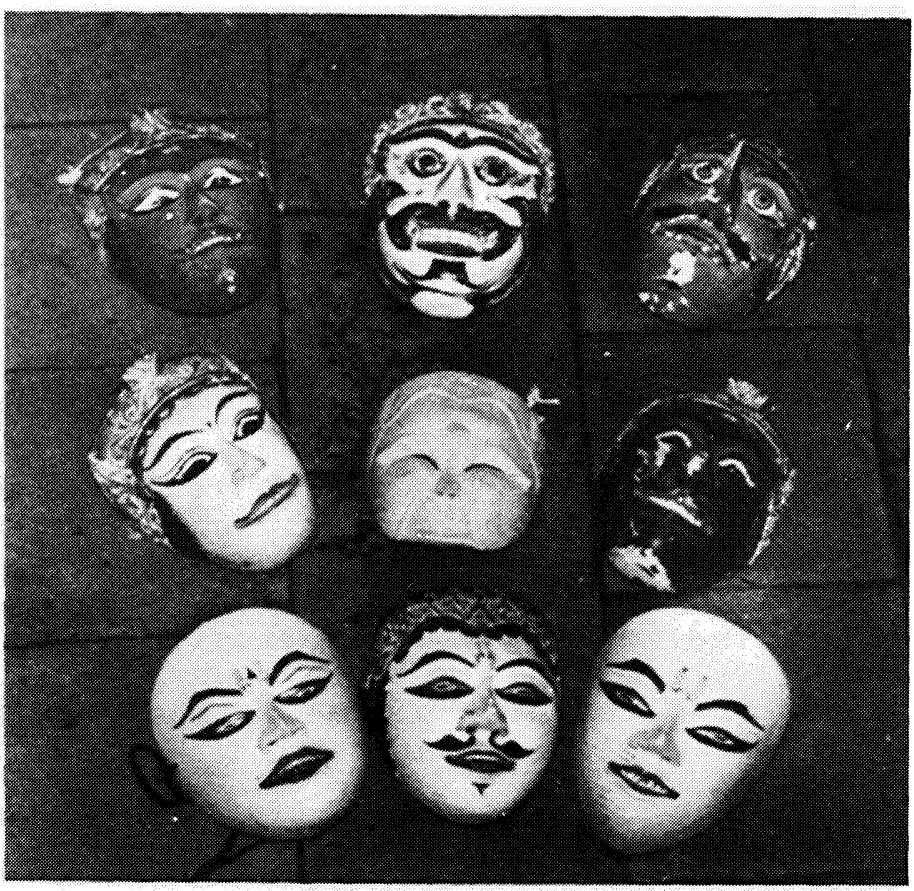

Top Row: Malang topèng carved by Kastawi of Polowidjen. Left to right, Pandji, a giant, Kelana (after a Central Javanese mode 1 ).

Middle Row: Malang topèng. Left to right, Pandji Anom, Punakawan, Pandji.

Bottom Row: Central Javanese (Jogjakarta) topèng. Left to right, Ragilkuning, Gunung Sahari, Ragilkuning.

Photo by Winifred Eaton 
crowned with the big leather djamang and the shiny beautiful masks smiling with big eyes seemed to dance mysteriously above a whirlwind of sampur and hands and feet in strong graceful movements throughout the performance.

The Djabung village performance was more informal than if it had been held outside the village. For instance, there was a continuous change of dalang. An old dancer from nearby Tumpang said that if a wayang topèng was held at the house of a wayang topèng leader, local dancers and dalang like to come to show off their abilities and hold a kind of competition. It is especially true when a topèng leader gives a wedding or circumcision feast for his children. This atmosphere was almost reached at the Independence Day topeng performance at Djabung. One did not feel that seven hours had passed when the end came at $30^{\prime} c l o c k$, just one hour before prayer time--in accordance with local custom to give people time to prepare for the morning prayers.

\section{The Topèng Troupe}

The wayang topèng troupe customarily consists of male dancers. There are no females; the female roles are taken by the male dancers. Moreover individual dancers have no fixed role. This troupe consisted of five adult dancers and nine child dancers between eight to tourteen years old. The wayang troupe always has child dancers who are from the same village as the adults. They are included in order to pass on the theater tradition to the younger generation. The entire troupe including musicians, helpers, and hangers-on numbered twenty to twenty-five persons. The topèng troupe leader is the spirit and pillar of the group. He is the production leader, often the dalang himself, and the owner of the costumes, topèng set, and gamelan. At the village of $\mathrm{Dj}$ abung he was a man called Kangsèn.

Kangsèn was a well situated villager. He lived in one of the largest stone houses and was a landowner as well. He belonged to the tjakal-bakal (founding families) of Djabung and was a man of repute and standing in the area. He was thought to have some sacred power or in any case to be a dukun ${ }^{23}$ who could be called upon to perform the rites at sacrifices or at the ngruwatan (exorcizing) ceremonies. Kangsèn was very conscious of these things; he liked to assert his position in the area. He declared proudly that "any time I want to run as lurah (village chief) I could do it. However, I do not feel like spending that much money for an election campaign and pawn my house and lands." Consequently the performance on Independence Day was held at his house instead of the village-chief's, al though there were some ill feelings about this. Another official, the young tjamat (lowest local official appointed by the central government), was only notified of the performance by invitation although ordinarily one needed an official permit from him for performances. Kangsèn claimed that since the performance was held for a national holiday, this was not necessary.

Kangsèn always dressed in black clothes: wide black trousers, a broad leather belt around the waist, a loose black jacket over a white

23. Medicine man, shaman. 


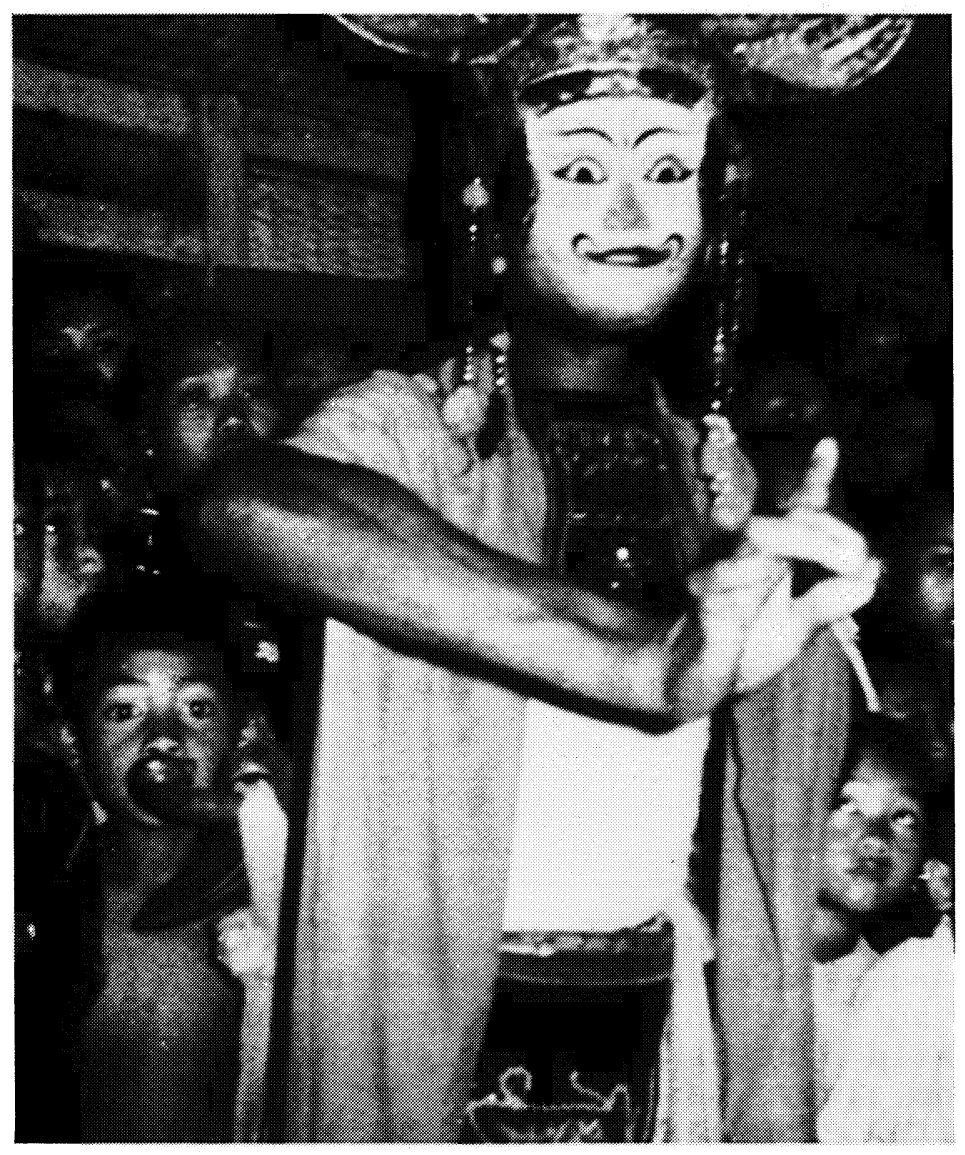

The star performer of the Djabung wayang topèng representing Gunung Sahari.

Photo by Winifred Eaton

The village performance at Djabung. The figure represented is Kelana.

Photo by Winifred Eaton

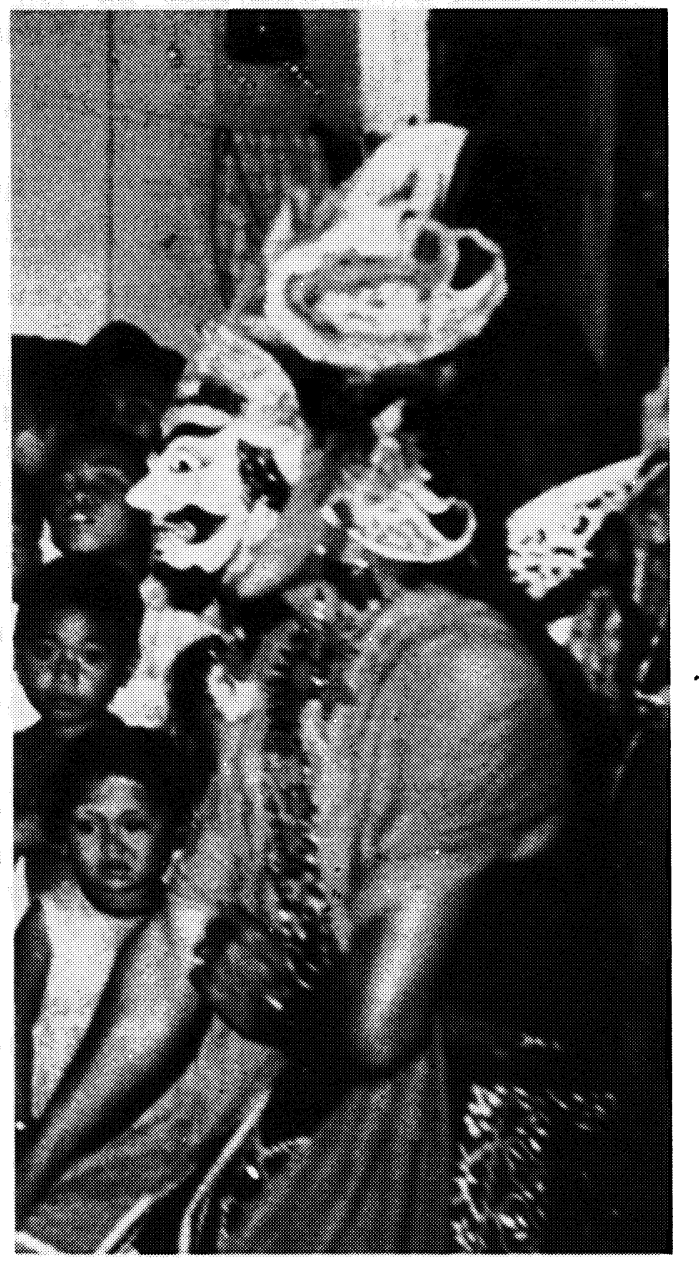


shirt, and a three pointed headdress. He had a compact slim body giving an impression of inner strength, and never smiled. He managed his group efficiently and oversaw every technical or artistic problem without any fuss even though Malang topèng members tend to be primadonnas who see themselves more as partners in the wayang topèng than as persons under Kangsèn's leadership.

It was not pure chance that Kangsèn was engaged in the topèng business. As is common in the Javanese art world, he inherited his position. Kangsèn's father was originally from the village of Polowidjen and a brother of Reni, the most famous topèng leader and carver of Polowidjen. Reni's patron was R.A.A. Soeria-adiningrat, the regent of Malang mentioned above. Reni had another brother Nita, who was equally famous as a wayang kulit carver. As neither Reni or Nita left sons, Reni's daughter sold Reni's famous gamelan as well as the wayang topèng and wayang kulit business after their deaths to the relatives at Djabung, Kangsèn and a brother-in-1aw of Kangsèn, who is we11 situated and has a wayang purwa business. The two relatives jointly own the Reni gamelan and are in fact business partners. In the performing world of Malang, one usually needs a business partner to share the many responsibilities. Despite the fact that the two relatives don't get along well personally, Kangsèn's performing business is a family affair benefitting from family cooperation. Kangsèn hired the tjikar to transport the wayang topèng group from his brotherin-1aw. Likewise Kangsen's brother-in-law hired Kangsèn's materials for a temporary stage for the wayang purwa performances. The wayang topèng costumes are mended by the wayang purwa dalang with help from both wives. It is the Reni gamelan which gives them their fame, as Kangsèn is not a particularly famous mask carver. Nevertheless, the family has more or less a monopoly over the performing arts of Malang or for some 30 to 50 kilometers. Their position in the performing world, their instruments and materia1s, and even the artistic skills of dancing, dalangship, and carving have been handed down within the family from generation to generation.

Kangsèn offered his house for the rehearsals of the troupe and provided them with coffee, tea, and sometimes cookies. in 1963 the topèng troupe got around Rp. 8,000 per performance and two full meals a piece as well as other provisions from whoever hired them. of this amount Kangsèn got the largest share and the dalang the next biggest part, if Kangsèn was not the dalang himself. If a performance was held at their own village, a tray was passed among the audience of about 150 adults to collect a payment. The adult dancers usually got only a token fee of Rp. 50 or less, and the child dancers got nothing except full meals before and after the performance.

The adult members of the troupe were well-situated peasants from the Djabung area, except for two laborers of Kangsen's. Several of these adult dancers helped run the performances and with technical problems. Kangsen's main star dancer, a married man of some means from Djabung, was his assistant in the problems of transporting the troupe's equipment, putting up the stage and placing the gamelan instruments. According to Kangsèn such responsibilities should be given to a man who has proven his sense of responsibity with duties in daily life. Kangsèn's artistic aid was a wandu (transvestite) who was also a well situated villager of Djabung. This man was sometimes the dalang and danced most of the female parts, though not exclusively. He was also the dance master checking cues and costuming. The two laborers quite often joined ludruk performing troupes inside and outside 
the village. Likewise the gamelan, also a permanent feature of Kangsèn's troupe, also performed for other "outside" performances . And a peasant from Tumpang, formerly a famous dancer in the 1ocality, is also attached loosely to the troupe as a dancer and dalang. In his youth he danced the now vanished bapang dance. At present he lives a leisurely life among his lèngkeng (fruit) trees near the ruins of the old $\mathrm{Tj}$ andi $\mathrm{Dj}$ ago. He occasionally joins Kangsèn's troupe on a voluntary basis and is paid a token fee for his participation. The two laborers did the rough work of building the set and lifting gamelan instruments, though no one, including Kangsèn, was unwilling to help if necessary.

\section{Polowidjen, Topèng Center of the Past}

Djabung is now the topèng center of the Malang-BlimbingTumpang area. Thirty to forty years ago, the village of Polowidjen due north of Malang on the road to Surabaya was the center. Polowidjen now has an urban look though it is still somewhat rural. There are several big houses built in the manner of present day Malang "villa" houses with large glass windows, and a number of sma11 Malang kampung (town neighborhood) style houses for nuclear families built half of bamboo and half of stone. The village copies a suburban idea with two long parallel streets, even though they are unpaved and agricultural land surrounds the village.

In the 1930's a well to do peasant called Reni lived in this village. He was one of the greatest topèng carvers of the Malang style and led one of the best wayang topèng troupes of his time. In today's wayang topèng world of Malang the village of Polowidjen is best known as Reni's village. In his day the wayang topèng achieved one of its high points. This development was certainly partly due to the patronage of the then bupati of Malang, R. A. A. Soeria-adiningrat, who supplied Reni with his materia1s (gold leaf, good paint, wood) and helped set artistic standards. Reni's masks are in the collections of princes and museums. Topèng collectors guard them as pusaka (heirloom). A Reni topèng is easily recognizable by its perfect proportions, fine carving, and skillful painting. None of his contemporaries or predecessors achieved the same high standards of artistic workmanship. In Malang, the Reni mask is considered the classic standard.

In the village of Polowidjen there is only one Reni mask left. It belongs to his daughter, Mbok Dari, a widow in her fifties, who lives in a simple and smali house with very handsome carvings inside. The mask represents a Ragilkuning figure (a princess in the Pandji cycle). It has perfect proportions and fine carvings on the djamang while the slightly carved eye-brows, eyes and mouth have strong and refined lines. Originally the face was painted with gold leaf. However, the colors have aged somewhat. The whole gives the impression of a dark sun-tanned and well oiled skin while the milky wax covering the face is like a thin transparent veil. The princess stares at you with an elusive, understanding "Buddha" smile. In her ears two diamond fragments glisten. The mask is probably one of Reni's best. It was perhaps ordered by a patron, but then kept by Reni when it was finished. Many artists tend to keep their best pieces. 
Locally this mask is thought to have magical powers and is a very revered pusaka. Mbok Dari treasures it as such. She keeps it in a white sack with the traditional melati (jasmine) and kenanga (a fragrant tree) flowers and burns incense before the mask every Thursday evening.

It is customary in Java that the most beautiful art works are thought to be sacred and not merely the result of mortal craftsmanship. The created object has its own spirit, the more powerful in those objects that are classically excellent. Sometimes it is thought that the artist is in a trance ${ }^{4}$ while working and that his works are divinely conceived. Others are loth to copy such works for fear of magical consequences. There is a mystical nature to all classical Javanese art, because the stories being told, the music being played, the scrolls being painted, for example, are representations of a divine legacy. Wayang topèng is included in this religious aspect of Javanese culture. The dalang is often thought to be a dukun or shaman (priest, medicine man), and the masks and dancers can also be revered. Famous gamelans are famous because they are pusaka. Because Javanese beliefs are attached to a kind of ancestor worship, pusakas are objects of worship to individual families, the village family, or the national racial family. Therefore it is thought that Reni's mask can only be used safely by a family descendant, and the village of Polowidjen gets its identity in the area from the pusaka wayang topèng located there. It is interesting to note also that because Reni's masks were probably ordered by a powerful personage such as a bupati, their sacredness is increased in the Javanese mind. That fact is derived from the Javanese understanding that socio-political hierarchies are a reflection of divine hierarchies.

On the other hand, there is a conflict of beliefs, albeit wellknown, with the growing power of Islam in Java that arises even in the Malang wayang topeng world. Islamic women are not allowed to attend topèng performances because the performances are said to invite immoral conduct in the audience, and the very existence of wayang is barely tolerated by the more devout Islamic circles because of the Islamic belief that wayang is idolatry despite the general

24. According to tradition, the mask carver might be inspired to carve a pusaka topèng by seeing the strangely formed branches of trees or driftwood on a river or because he had dreams of these things or of a special mask. In Polowidjen under the care of the family of the ludruk leader, there is a wayang èplèk set (wayang figures made of sugar-palm leaves) of great magical power in the past. This pusaka set's origin is shrouded in village myths and legends. It is said that one day long ago a local villager slept under $a$ palm tree and dreamed that he had to make wayang figures out of the palm leaves. He was awoken by a falling palm leaf. He made the wayang èplèk set and it became the village pusaka to ward off evil and cure sickness. The set, rather primitively made, indeed appeared to be very old and probably dated from the days of the village's founding. Nowadays, however, the pusaka set no longer plays a part in village ritual and is no longer used as a magic object. No one could remember it being shown at a performance, in fact. The set is just kept in a box in the home of an old village family. 
entertainment. The most recent influence on wayang topèng, however, comes from its commercialism. The result is a secularization of the art.

Kastawi, The Topèng Carver of Polowidjen

Today in the village of Polowidjen a man named Kastawi is the only one engaged in the wayang topèng business. He is a descendant of Reni and therefore able to use the pusaka mask and fulfill the requirements of an inheritor of the art. He is well known as a mask carver, though from lack of a patron his masks are less luxurious than Reni's. Until ten years ago he had a wayang troupe. However, the village became more and more integrated with the urban life of Malang and its attractions of wayang orang, ludruk and movie theaters. The villagers began being employed in Malang as laborers, truck drivers, carpenters and furniture makers. People lost interest in the the wayang topèng and preferred the ludruk and wayang orang. For the last ten years there has not been a topèng performance in the village despite its tradition, except for a travelling show of Ponorogo Reog. ${ }^{25}$ Kastawi's topèng group fell apart and he went over to lead a wayang orang group. Another reason for the end of Kastawi's group was that he could not compete with his relatives' Djabung group with its famous bronze gamelan. His was only an iron gamelan of mediocre qualities.

What Kastawi has been doing as a mask carver for the last five years indicates the situation of the area's topèng tradition. A peranankan-Chinese businessman from Malang ordered from him some forty pairs of masks in the Central Javanese tradition instead of the Malang tradition. He needed these masks for his children's dance school, which teaches the Central Javanese dance style. The masks are the Kelana and Gunung Sahari26 figures. Nevertheless, according to Kastawi, some of the Malang tradition has been brought over into these Central Javanese masks. Occasionally Kastawi still carves masks in the Malang style for other wayang troupes in the area or for himself, but he is mainly engaged as a carpenter and furniture maker. Kastawi carves masks and is engaged in wayang orang in his leisure time.

Kastawi gets around Rp. 750 for one mask, or the price of one to two liters of rice. It takes a week to ten days of continuous working to complete a mask. One certainly can not live from the trade and support a family. The money earned is just enough to keep the tradition of mask carving alive. Kastawi himself gets some slight profit from the price paid for a mask. He buys his materials himself and uses the excess paint and wood to carve other masks for himself or for orders. For instance, he carved some dozen masks in

25. A form of wayang topèng if the literal meaning of wayang topèng as mask dance perfromance is used. It is a mask dance of a small number of figures, most notable among them being a fearsome tiger with a peacock standing on top of it, and another red kelana figure. This group originated in Ponorogo; they travelled to accompany such festivities as weddings.

26. Javanese hero in the Pandji cycle. 
the Malang style with the wood and paint leftover from the order of forty pairs of Central Javanese masks. Those he carves for himself are usually his cherished figures such as Pandji Anom, ${ }^{27}$ Gunung Sahari and Kelana. When the need arises or the opportunity comes, Kastawi se11s these masks. None of his works are yet considered pusaka masks. His work is more strongly directed toward furniture carving. Nevertheless he observes the necessary sacrifices and ceremonies of incense burning and fasting before beginning a topèng.

A fellow villager, engaged in the ludruk business, observed that Kastawi was an orang kuno (man of the past, older generation). He probably meant that Kastawi felt bound to the tradition of oral literature in wayang topèng whereas he could assert himself more freely in ludruk by adopting any part of the environment for his use.

Kastawi will probably be the last one at Polowidjen to carve masks and continue in some way the topèng tradition of the past. He has no pupils or assistants who could replace him as Reni once had. However, the carpenter and furniture making business is left to the village from its days as a center of wayang topèng. Many of the present day villagers at Polowidjen are now engaged in this business. To the furniture industries of the town of Malang, the village is known as a center of "Old Dutch Furniture" (an Indonesian version of East India Company style furniture). To the villagers of Polowidjen it is known as mebel antik (antique furniture) with carvings closely related to the topèng decorations.

\section{The Spread of Topèng in Malang}

The decline of topèng in Polowidjen does not represent the real situation of the wayang topèng in Malang. Fortunately for this culture, Kangsèn, Mbok Dari, and Kastawi are not the only representatives of the topeng. Spread out over the area there are still other carvers, and on the Malang-Kepandjèn side there are well known carvers and people fully engaged in the wayang topèng business. South of Malang towards the famous beach of $\mathrm{Nglijep}$, in the village of Senggreng, a father and son are al1-round experts in the local arts. They have a wayang topèng troupe, dance, carve topèng as well as wayang purwa and kulit puppets and act as dalang. Kepandjèn is also an active center of wayang topèng. There are several topèng troupes in the area, one at Sumberputjung a village located on the road from Malang to Blitar, and another at $\mathrm{Ng} 1 \mathrm{ijep}$. The relatively large number of performing groups and the competition in the area. make it necessary that the local artist be an expert in many different art forms in order to maintain himself.

Many patrons of wayang topèng who have usually inherited a few pusaka masks of great fame are responsible to a great extent for supporting the topèng tradition in Malang. They build complete sets of topèng around their pusaka ones and keep alive their myths. Furthermore, they generally help maintain the art itself by their patronage of the troupes and carvers, and by their knowledge of the examples set by artists in the past.

27. A Javanese hero, Pandi, in his youth. 
In the kabupatèn of Malang there are several famous mask sets. The village chief of Putjangsongo, ${ }^{28}$ five kilometers from Tumpang in the direction of $\mathrm{Tj}$ andi Kidal, inherited nine Reni masks. Ten years ago he had a local carver supplement them with over forty more masks and established a troupe of twelve dancers. His topèng set is used for the annual village festivities where a wayang performance is traditionally given. He also rents out his wayang topèng set to other villages and individuals attracted to its pusaka "core." 29 There is another famous pusaka set of topèng in the village of Senggreng which is used in the same way as that of Putjangsongo.

Not a11 topèng sets in the Malang area, however, have a core collection of pusaka masks. For various reasons severai sets were for sale in 1963. At that time an ordinary set complete with costumes sold for about Rp. 40,000-45,000. To order a new set cost double that amount, because the price would include maintaining the artist and his family's daily livelihood.

It is the pusaka topèng, great either through beauty or legend, worn by a famous dancer for the traditional Pandji stories that keep the people of Malang fascinated by the wayang topèng. This is especially true if it is said that the mask could charm people or has a special magical power such as would enable it to ward off sickness or make the rains come down. No such magic topeng exists in the kabupatèn of Malang. Still it is said that such a mask exists in the caves of Blitar, or in the mountain or jungle villages of Kediri.

Meanwhile, in the Malang region itself, all the known pusaka topèng can be traced to famous carvers in living memory. They were skillfully enhanced by the carver and became legendary after the carver's death. At some future date, if the pusaka mask of Mbok Dari or the beautiful topèng in the possession of others pass into new hands, then complete wayang topeng sets might be built around them, too. The Malang wayang topèng tradition is not yet dead. As a topèng dancer from Tumpang said, "we do the same things in wood that our ancestors did in stone," pointing to the carvings on the ruins of $\mathrm{T} j$ andi Tumpang which represent in stone the rhythm of 1 ife.

28. Pigeaud, Javaanse Volksvertoningen, p. 142 mentions Putjangsongo as a wayang topeng center.

29. A leader of a topèng troupe might be tempted to pawn his topèng set during a bad harvest or if he needed money, especially during the fasting month when performances are not allowed, or during quiet topèng seasons. 